\title{
Imigranci a innowacyjność państw przyjmujących: przypadek Polski
}

\author{
MAŁGORZATA WACHOWSKA ${ }^{1}$ \\ Instytut Nauk Ekonomicznych, Uniwersytet Wrocławski
}

Ze względu na fakt, że wysoko wykwalifikowanych imigrantów uważa się za źródło cennego know-how i rozprzestrzeniania się wiedzy, artykuł skupia się na korzyściach wynikających z międzynarodowej mobilności wynalazców z perspektywy innowacyjności polskiej gospodarki, która mierzona jest liczbą wynalazków. Na podstawie analizy międzynarodowych zgłoszeń patentowych stwierdzono, że 12\% produktu wynalazczego Polski z lat 2004-2018 stanowiły rozwiązania techniczne tworzone przez cudzoziemców, głównie obywateli Niemiec, a w dalszej kolejności Francji i Stanów Zjednoczonych Ameryki.

Słowa kluczowe: międzynarodowe przepływy wiedzy, międzynarodowe migracje ludności, innowacyjność, wynalazcy, Polska

\section{Immigrants and innovation of host countries: the case of Poland}

Due to the fact that highly skilled immigrants are considered to be a source of valuable know-how and knowledge diffusion, the paper focuses on the benefits of international mobility of inventors from the perspective of innovation in the Polish economy, which is measured by the number of inventions. Based on the analysis of international patent applications, it was found that $12 \%$ of Poland's inventive product from 2004-2018 were technical solutions created by foreigners, mainly German citizens, followed by citizens France and the United States of America.

Keywords: international knowledge flows, international migration, innovation, inventors, Poland

\section{Wstęp}

Po tym jak w 2004 r. Polska przystąpiła do Unii Europejskiej (UE), w której obywatelom przysługuje prawo swobodnego przepływu pracowników, nasiliły się ruchy migracyjne z Polski (Kaczmarczyk 2015; Lesińska i in. 2014; Okólski 2009;

1 Kontakt: malgorzata.wachowska@uwr.edu.pl 
Grabowska-Lusińska, Okólski, 2009; Garapich i in. 2018). W porównaniu z migracjami przedakcesyjnymi charakteryzują się one większym udziałem jednostek wysoko wykwalifikowanych, co jest niewątpliwie ogromną stratą dla Polski, gdyż wraz z ich odpływem, utracona zostaje ich wiedza i umiejętności, w wyniku czego mogą zmniejszyć się zdolności do absorpcji i generowania innowacji w kraju.

Z perspektywy Polski zasadniczym pytaniem jest zatem, czy może ona rekompensować sobie utratę najcenniejszego kapitału ludzkiego, np. uzyskując dostęp do wiedzy krajów docelowych poprzez połączenia z krajową diasporą czy migrację powrotną lub poprzez napływ wysoko wykwalifikowanych cudzoziemców, którzy mogliby stanowić cenne źródło wiedzy i rozprzestrzeniania się know-how?

Niniejszy artykuł koncentruje się na tym ostatnim z potencjalnych mechanizmów kompensujących państwom utratę talentów. Celem artykułu jest oszacowanie wkładu, jaki wnoszą imigranci w podnoszenie innowacyjności polskiej gospodarki, mierzonego liczbą wynalazków zgłaszanych do ochrony patentowej w trybie międzynarodowym. W artykule rozważane są dwie zasadnicze kwestie: (1) ile wynalazków, zarówno w ujęciu absolutnym, jak i procentowym, generują cudzoziemcy na rzecz polskich podmiotów? oraz (2) czy większa liczba imigrantów przebywających na terenie Polski skutkuje większą liczbą wynalazków, których twórcą jest cudzoziemiec?

W celu ustalenia liczby wynalazków tworzonych przez cudzoziemców na rzecz Polski, przeanalizowano międzynarodowe aplikacje patentowe (PCT: Patent Cooperation Treaty) składane $w$ latach 2004-2018 przez polskie podmioty pod kątem zarówno obywatelstwa, jak i miejsca rezydencji wynalazcy. Ostatecznie analizą objęto 2549 zgłoszeń patentowych.

Pozostała część artykułu zorganizowana jest w następujący sposób. W punkcie pierwszym zawarto krótki przegląd literatury z perspektywy roli imigrantów w podnoszeniu poziomu innowacyjności kraju przyjmującego. W drugim, opisano dane i metody zastosowane $w$ tym opracowaniu. W trzecim, przedstawiono dane obrazujące liczbę imigrantów w Polsce. Wyniki badań przedstawiono w punkcie czwartym, a w końcowym - główne wnioski oraz kierunki przyszłych badań.

\section{Migracja a innowacyjność. Przegląd literatury}

Ze względu na fakt, że innowacje i ich rozprzestrzenianie się są kluczowymi czynnikami zrównoważonego wzrostu i rozwoju gospodarczego, coraz więcej badań skupionych jest wokół mechanizmów, dzięki którym kraje mogą pozyskiwać zagraniczną wiedzę i czerpać korzyści z efektów prac B+R prowadzonych przez obce gospodarki narodowe. Ponieważ jednym z mechanizmów przenoszenia i rozpowszechniania wiedzy w skali międzynarodowej jest mobilność kapitału ludzkiego, coraz więcej badaczy analizuje zależność między innowacyjnością kraju a obecnością i różnorodnością etniczną imigrantów. 


\section{SM̂PP}

Niestety większość z tych badań skupia się jedynie na Stanach Zjednoczonych Ameryki jako jedynym kraju przeznaczenia, de facto pomijając fakt, że inne kraje rozwinięte również odnoszą sukcesy w zakresie przyciągania talentów z zagranicy. Dodatkowo, niektóre zdają się pomijać fakt, że wpływ imigrantów na wyniki innowacyjne jest zależny od rodzaju wiedzy czy kwalifikacji mobilnych osób, analizując wkład imigrantów bez rozróżniania ich według poziomu umiejętności. I w końcu, ze względu na ograniczoność danych, część badań stanowi studium przypadków indywidualnych migrantów i indywidualnych miejsc pracy, w których źródłem informacji na temat roli mobilności kapitału ludzkiego w podnoszeniu poziomu innowacyjności są dane pochodzące $z$ ankiet przeprowadzanych wśród migrantów lub przedsiębiorstw zatrudniających migrantów.

Ogólnie zdecydowana większość opracowań, odnoszących się do efektów międzynarodowej migracji kapitału ludzkiego dla szeroko rozumianej innowacyjności gospodarek przyjmujących, odnajduje dodatnią zależność między tymi dwoma zjawiskami. Nie ma przy tym znaczenia czy badania skupiają się na konkretnym kraju docelowym, czy też koncentrują się na wybranej mobilnej grupie etnicznej i szacują jej wkład w podnoszenie zasobów wiedzy różnych gospodarek narodowych (np. Edler, Fier, Grimpe 2011). Odkrycia tych badań wpisują się w ogólnie panujący pogląd, że kraje odnoszą korzyści z napływu wysokiej klasy specjalistów, naukowców czy inżynierów.

Wśród badań stanowiących wsparcie dla powszechnie formułowanej hipotezy, według której wysoko wykwalifikowani imigranci promują innowacyjność państw przyjmujących, należą przede wszystkim analizy odnoszące się do Stanów Zjednoczonych Ameryki. Można do nich zaliczyć m.in. opracowanie Stephan i Levin (2001), które stwierdzają, iż jednostki urodzone za granicą dokonują ponad proporcjonalnego wkładu w naukę USA oraz są źródłem siły i witalności amerykańskiej nauki. Do podobnych wniosków dochodzą Wadhwa i in. (2007), których badania sugerują, że osoby z obcym obywatelstwem przebywające w USA, zwłaszcza Chińczycy i Hindusi, mają znaczący udział w amerykańskim produkcie wynalazczym. Kerr (2009) dowodzi natomiast, że imigranci przyczyniają się do szybszej adaptacji przełomowych innowacji przez Amerykanów, a Kerr i Lincoln (2010), że imigranci z Chin i Indii promują wynalazczość w USA w większym stopniu niż europejscy wynalazcy. Znaczącą rolę wysoko wykwalifikowanych imigrantów w podnoszeniu innowacyjności Stanów Zjednoczonych Ameryki podkreślają także Hunt (2011) oraz Hunt i Gauthier-Loiselle (2010), które analizują zależność między obecnością imigrantów a liczbą patentów w Stanach Zjednoczonych. Hunt (2011) stwierdza, że imigranci, którzy po raz pierwszy wjechali do Stanów Zjednoczonych na wizę studencką lub wizę pracy tymczasowej mają przewagę nad tubylcami w zakresie patentowania, komercjalizacji i licencjonowania patentów i pod tym względem przewyższają także imigrantów, którzy przybyli w późniejszym okresie swojego życia. Natomiast Hunt i Gauthier-Loiselle (2010) wskazują, że wzrost liczby naukowców i inżynierów imigrantów oraz wzrost liczby imigrantów w szkołach średnich o odpowiednio - 0,45 oraz 1 punkt 
procentowy zwiększa liczbę patentów na jednego mieszkańca, czyli proporcjonalnie o około $13 \%$ i $9-18 \%$.

W podobnym tonie wypowiadają się autorzy badań analizujący efekty napływu obcokrajowców do innych niż Stany Zjednoczone Ameryki gospodarek narodowych, choć w tym przypadku można wskazać także analizy, których autorzy nie odnajdują dodatniej lub wręcz negatywną zależność między migracją a innowacją. Ograniczając swe rozważania do gospodarki Niemiec, Niebuhr (2010) zauważa, że różnorodność kulturowa pozytywnie wpływa na innowacyjność i w tym sensie wysoko wykwalifikowani pracownicy z zagranicy przyczynią się do wzrostu wydajności regionalnej sektorów B+R. Co więcej, korzyści z tej różnorodności przewyższają negatywne skutki związane z napływem obcokrajowców. W odniesieniu zaś do Kanady, Partridge i Furtan (2008) formułują wniosek, że wykwalifikowani imigranci ze Stanów Zjednoczonych oraz rozwiniętych państw Europy, a także państw rozwijających się Europy Wschodniej i Azji, zwiększają innowacyjność regionów Kanady. Z tymi wynikami spójne są badania Oettl i Agrawal (2008), którzy - skupiając się na mobilnych wynalazcach z Niemiec - przekonują, iż Kanada zyskuje zasoby ich wiedzy i umiejętności. Z kolei Parotta i in. (2012) przekonują, że różnorodność etniczna wśród wynalazców odgrywa ważną rolę w napędzaniu innowacyjnych wyników przedsiębiorstw w Danii.

W tym kontraście Ozgen i in. (2013) wskazują, że wśród pracowników firm zlokalizowanych w Holandii większy odsetek cudzoziemców obniża innowacyjność przedsiębiorstw, natomiast Bratti i Conti (2018) stwierdzają, że we Włoszech ani imigranci wysoko ani nisko wykwalifikowani nie mają wpływu na innowacje mierzone liczbą patentów.

Z powyższego zestawienia wynika zatem, że wysoko wykwalifikowani imigranci nie zawsze są źródłem kreatywności i sprzyjają działalności innowacyjnej. Między innymi dzieje się tak dlatego, że różnorodność etniczna wśród pracowników może być jednocześnie przyczyną nieporozumień i konfliktów, a tym samym barierą dla innowacji (Basset-Jones 2005). Ponadto rola imigrantów w stymulowaniu innowacji może również zależeć od tego, czy ich wiedza i umiejętności są bardziej komplementarne, czy substytucyjne wobec wiedzy pracowników lokalnych. Nie bez znaczenia jest również struktura imigrantów. Zgodnie z neoklasyczną teorią ekonomii, gdy dużą część migrujących pracowników stanowią osoby z niskimi płacami (nisko wykwalifikowane), wówczas przedsiębiorstwa opracowują strategię ekspansji wykorzystującą pracochłonną technologię produkcji. Jednocześnie może to oznaczać, że mniej zasobów zostanie przeznaczonych na innowacje.

Wnioski z neoklasycznej teorii ekonomii tłumaczą po części, dlaczego Stany Zjednoczone Ameryki zyskują wraz z napływem cudzoziemców. Jako kraj znany ze stosowania selektywnej polityki imigracyjnej, ukierunkowanej na pozyskiwanie talentów, USA zapewniają sobie korzystną strukturę imigrantów, w której relatywnie duży udział mają jednostki wybitne. Należy się zatem spodziewać, że kraje, które 32 z różnych względów mają niewielki potencjał w przyciąganiu wysoce kreatywnych 


\section{SM̂PP}

imigrantów w relacji do cudzoziemców o niskich kwalifikacjach, będą miały mniejszą szansę osiągnąć korzyści w postaci zwiększonej innowacyjności.

Niniejsze opracowanie wnosi wkład w dyskusję na temat roli mobilności wysoko wykwalifikowanych jednostek w stymulowaniu innowacyjności państw przyjmujących na dwa sposoby. Po pierwsze, analiza jest ograniczona do dość homogenicznej grupy imigrantów, dokładniej wynalazców PCT, których można uznać za wybitne jednostki o wysoce kreatywnym kapitale ludzkim. Uwzględnia przez to fakt, iż wyniki w zakresie innowacyjności mogą być różne w zależności od stopnia zaawansowania wiedzy i umiejętności mobilnych osób. Po drugie, dostarcza dowodów dla kraju, Polski, który ostatnio doświadcza fali imigrantów, przy czym niewielu spośród nich wyróżnia się wybitnymi kwalifikacjami i umiejętnościami (zob. pkt 3). Autorzy dotychczasowych badań skupiających się na Polsce jako kraju przyjmującym nie analizują efektów związanych z napływem wynalazców do Polski.

\section{Dane i metoda badań}

\subsection{Dokumentacja patentowa PCT w badaniu efektów międzynarodowej migracji wynalazców}

Oficjalne statystyki migracyjne są mało szczegółowe, jeśli chodzi o wykształcenie migrantów i wiązanie tego wykształcenia z innymi charakterystykami migracji. Zasadniczo dane dotyczące osiągnięć edukacyjnych migrantów gromadzone są jedynie przez $\mathrm{OECD}$, niestety są one mało usystematyzowane.

Jednym z alternatywnych źródeł danych o migrantach wysoko wykwalifikowanych, a dokładniej o migrujących wynalazcach, są dokumenty patentowe. Stanowią one nie tylko cenne źródło informacji na temat m.in. aktywności innowacyjnej i zakresu współpracy badawczo-rozwojowej podmiotów czy wielkości i dynamiki przepływów wiedzy, ale także pozwalają na śledzenie ścieżek migracyjnych wynalazców oraz ich produktywności wynalazczej. Wynika to z faktu, że dokumenty patentowe zawierają podstawowe dane o wynalazcach i zgłaszających patenty, a także o samym wynalazku, takie jak nazwisko i imię wynalazcy, jego miejsce zamieszkania w okresie przygotowywania aplikacji patentowej (zazwyczaj jest to jednocześnie dzień składania wniosku patentowego), nazwę i miejsce siedziby zgłaszającego, obszar technologiczny wynalazku, datę złożenia wniosku patentowego czy cytowania patentowe (odwołania do cudzej, wcześniejszej publikacji czy patentu).

Z perspektywy identyfikacji imigrantów wynalazców w wybranym kraju docelowym, szczególnie użyteczne są informacje dotyczące obywatelstwa i miejsca zamieszkania wynalazcy. Pozwalają one ustalić liczbę imigrantów wynalazców o określonym pochodzeniu etnicznym (a dokładniej obywatelstwie) przebywających w określonym kraju przyjmującym w okresie przygotowywania aplikacji patentowej (zazwyczaj także w dniu 
złożenia wniosku patentowego). Jeśli te informacje połączymy z danymi dotyczącymi samego wynalazku, to możliwe staje się określenie liczby i struktury wynalazków tworzonych w poszczególnych państwach docelowych przez grupy imigrantów legitymujących się określonym obywatelstwem. Niestety jedynie w międzynarodowych aplikacjach patentowych PCT (do 16.09.2012 we wszystkich, a później jedynie w niektórych) ujawniane jest obywatelstwo twórcy wynalazku, w zgłoszeniach patentowych dokonywanych w trybie krajowym czy regionalnym, wynalazcy nie podają takiej informacji.

Formularz wniosku patentowego PCT został opracowany przez Światową Organizację Własności Intelektualnej (WIPO). Jest to jedyny formularz patentowy, w którym podanie informacji o obywatelstwie zgłaszającego jest obowiązkowe. Ze względu na fakt, że do 16.09.2012 istniała konieczność wymieniania wśród zgłaszających (de facto właścicieli wynalazku) również twórców wynalazków, stąd oni również byli zobowiązani do ujawniania swojego obywatelstwa. Niestety, ze względu na wprowadzone 16.01.2012 zmiany w prawie patentowym Stanów Zjednoczonych Ameryki, nie we wszystkich wnioskach PCT składanych po 16.09.2012 wskazywane jest obywatelstwo twórców wynalazków (szczegóły zob. Miguelez, Fink 2013), jako że nie wszyscy twórcy wynalazków są wymieniani wśród zgłaszających. Stany Zjednoczone Ameryki w ramach Leahy-Smith America Invents Act (AIA) zlikwidowały obowiązek wymieniania wynalazców jako zgłaszających w tych zgłoszeniach PCT, w których USA są wskazywane jako tzw. kraj wyznaczony w zgłoszeniu (kraj, w którym zgłaszający rozważa staranie się o ochronę patentową). Do zgłaszającego należy decyzja czy wynalazców łączyć ze zgłaszającym. W praktyce część zgłaszających skorzystała z możliwości niewymieniania twórców wynalazków wśród zgłaszających.

\subsection{Zakres i metoda badań}

W toku badań podjęto próbę oszacowania liczby wynalazków zgłaszanych do ochrony patentowej na rzecz Polski tworzonych przez cudzoziemców przebywających w Polsce (zarówno na pobyt stały, jak i czasowy) oraz odpowiedzi na pytanie, czy większa liczba napływających do Polski imigrantów przekłada się na większą liczbę wynalazków tworzonych przez cudzoziemców na rzecz Polski.

Analizą empiryczną zostały objęte międzynarodowe zgłoszenia patentowe (PCT) z lat 2004-2018 dokonane przez podmioty z Polski. Przez zgłoszenia podmiotów z Polski rozumie się przy tym jedynie te wnioski, które zostały złożone przez polskie podmioty z siedzibą zlokalizowaną na terytorium Polski. Z analizy wyłączone zostały tzw. zgłoszenia indywidualne, które przy mieszanym składzie etnicznym wynalazców, będących zarazem zgłaszającymi, uniemożliwiają jednoznaczne przypisanie aplikacji patentowej do określonego kraju. Ostatecznie próba badawcza składała się z 2549 zgłoszeń patentowych PCT dokonanych przez polskie podmioty.

W celu ustalenia liczby wynalazków tworzonych przez cudzoziemców na rzecz 34 Polski przeanalizowano objęte badaniem zgłoszenia patentowe PCT pod kątem 


\section{SM̂PP}

zarówno obywatelstwa, jak i miejsca rezydencji wynalazcy. Do wynalazków tworzonych przez cudzoziemców zgłaszanych do ochrony patentowej w latach 2004-2012 zaliczono te aplikacje patentowe, w których wynalazca niezależnie od miejsca rezydencji wskazał, że posiada inne niż polskie obywatelstwo. Spośród 145 aplikacji tego typu zaledwie w sześciu przypadkach obywatel innego niż Polska państwa wskazał miejsce rezydencji na terytorium Polski. Niewielka liczba rezydentów Polski wśród cudzoziemców wynalazców może oznaczać, że jedynie nieliczni przebywają w Polsce na stałe (szerzej o problemach związanych z interpretacją miejsca rezydencji wskazywanych w aplikacjach patentowych zob. pkt 2.3).

W latach 2013-2018 wynalazki generowane przez cudzoziemców zostały zidentyfikowane zarówno w oparciu o wskazane obywatelstwo wynalazcy (jeśli taka informacja była podana), jak i miejsce rezydencji wynalazcy. W konsekwencji do rozwiązań technicznych tworzonych przez cudzoziemców na rzecz Polski zaliczono te, których twórcą był albo badacz posiadający inne niż polskie obywatelstwo albo rezydent innego niż Polska kraju (o słabości takiego podejścia szerzej zob. pkt 2.3).

Początek okresu badawczego, obejmującego lata 2004-2018, jest zbieżny z rokiem, kiedy Polska przystąpiła do UE.. Z perspektywy ruchów migracyjnych ludności zarówno z, jak i do Polski jest to rok przełomowy. Z jednej strony, otwarcie w tym roku zagranicznych rynków dla pracowników z Polski wywołało masową emigrację Polaków, z drugiej - Polskę jako pełnoprawnego członka UE cudzoziemcy zaczęli postrzegać jako atrakcyjne miejsce do pracy i zamieszkania. Analizę zakończono na ostatnim roku, za który dostępne są dane wykorzystywane w badaniu.

\subsection{Ograniczenia badań}

Niewątpliwą zaletą danych dotyczących migracji pochodzących z aplikacji patentowych jest ich większa precyzja aniżeli danych pochodzących z krajowych statystyk, które są jedynie danymi szacunkowymi. Dane patentowe są również lepsze niż dane pochodzące ze spisów powszechnych, ponieważ pozwalają na lepsze porównania międzynarodowe. Badania opierające się na danych pochodzących ze spisów powszechnych cechuje pewna nieporównywalność w zakresie wpływu imigrantów z poszczególnych państw na tworzenie zasobów wiedzy kraju docelowego. Pewne kraje definiują bowiem migrantów na bazie obywatelstwa, podczas gdy inne wykorzystują kryterium kraju urodzenia. Korzystanie z danych patentowych pozwala także na dość dokładne oszacowanie efektów pracy wynalazców-imigrantów (Wadhwa i in. 2007; Kim i in. 2009; Bahar i in. 2019), w przeciwieństwie do badań, w których na podstawie dodatniej korelacji np. między wzrostem liczby wysoko wykwalifikowanych imigrantów i wzrostem liczby patentów w kraju otrzymującym domniemywa się, że migracja kapitału ludzkiego przekłada się na wzrost poziomu innowacyjności kraju przyjmującego (Chellaraj i in. 2005; Hunt, Gauthier-Loiselle 2010; Bratti, Conti 2018). 
I w końcu dane patentowe pozwalają ograniczyć badania do wąskiej, w miarę homogenicznej grupy wysoko wykwalifikowanych migrantów wynalazców, przez co ostateczne wnioski z badań charakteryzuje większy walor aplikacyjny.

Pomimo swoich wielu zalet, badania migracyjne wykorzystujące dane patentowe, w tym także analiza podjęta w niniejszym artykule, mają swoje ograniczenia. Przede wszystkim, pozwalają jedynie na formułowanie wniosków odnośnie do liczby przebywających w danym roku w określonym kraju wynalazców z poszczególnych stron świata, nie pozwalają jednak na jednoznaczne stwierdzenie, w którym roku wynalazca opuścił swój kraj. Dla przykładu, w grupie wynalazców z Francji przebywających na terenie Polski, którzy, np. w 2010 r. stworzyli i zgłosili do opatentowania wynalazek (co wynika z dokumentacji patentowej), mogą znajdować się osoby, które przybyły do Polski we wcześniejszych okresach. Ponadto, dokumenty patentowe pozwalają jedynie określić obywatelstwo wynalazcy (i to jedynie w przypadku aplikacji patentowych $P(T)$, co oznacza, że w badaniach wykorzystujących dane patentowe można pominąć efekty pracy twórczej długoterminowych migrantów, którzy otrzymali obywatelstwo kraju przeznaczenia przed złożeniem wniosku patentowego.

Z perspektywy rozważań podjętych w artykule, jednym z większych ograniczeń jest jednak to, że informacje patentowe de facto nie pozwalają jednoznacznie określić miejsca czasowego pobytu wynalazców. W formularzu PCT informacja o miejscu rezydencji wynalazcy jest traktowana raczej jako informacja o adresie do korespondencji aniżeli o miejscu czasowego czy stałego pobytu wynalazcy. W efekcie wynalazca może część życia spędzać w kraju przyjmującym, pracując na jego terenie, ale z różnych powodów wskazywać swój kraj pochodzenia jako miejsce rezydencji. Dotyczyć to będzie przede wszystkim cudzoziemców, którzy czasowo przebywają w kraju przyjmującym. Stąd też czasowi migranci mogą być pominięci przy identyfikowaniu imigrantów wynalazców w sytuacji, gdy do imigrantów zaliczani są jedynie ci badacze, którzy jednocześnie posiadają obce obywatelstwo i są rezydentami kraju przyjmującego.

W celu pokonania powyższego ograniczenia, w niniejszym artykule rezydencja wynalazcy na terenie Polski nie była warunkiem koniecznym, aby wynalazek został zakwalifikowany do tworów pracy cudzoziemców na rzecz Polski (zob. pkt 2.2). Do wynalazków tworzonych przez cudzoziemców zostały bowiem zaliczone wszystkie rozwiązania techniczne, których twórcą była osoba posiadająca obce w stosunku do polskiego obywatelstwo, niezależnie od miejsca zamieszkania (dotyczyło to wszystkich aplikacji z lat 2004-2012 oraz aplikacji z lat 2013-2018, w których informacja o obywatelstwie została podana).

Drugim istotnym ograniczeniem badań podjętych w artykule jest fakt, iż informacja o obywatelstwie wynalazców jest każdorazowo wskazywana jedynie w aplikacjach patentowych PCT złożonych do 16.09.2012 r., w późniejszych aplikacjach informacja o obywatelstwie wynalazcy ujawniana jest wybiórczo, co utrudnia określenie jego kraju pochodzenia. Część badaczy migracyjnych próbuje ominąć ten problem, określając pochodzenie wynalazcy na podstawie analizy etnicznego pochodzenia jego nazwiska 


\section{SM̂PP}

(Kerr 2008a, 2008b; Kerr 2009; Kerr, Lincoln 2010; Agrawal i in. 2011; Nathan 2015). Ta metoda jest jednak daleka od doskonałości, pozwalając (jeśli w ogóle) określić raczej region aniżeli kraj, z którego pochodzi wynalazca. Ponadto łatwo o pomyłki w przypadku migrantów, którzy zmienili nazwisko. Dotyczy to przede wszystkim kobiet, które wychodząc za mąż za obywatela kraju docelowego, przyjmują jego nazwisko.

W celu pokonania tego ograniczenia, w odniesieniu do lat 2013-2018 zostało przyjęte założenie, że wynalazcy-rezydenci określonego kraju są jednocześnie jego obywatelami. Stąd do wynalazków tworzonych przez cudzoziemców na rzecz Polski zostały zaliczone wszystkie te, których twórcą był rezydent innego niż Polska kraju (zob. pkt 2.2). Wprawdzie takie założenie niesie ryzyko pomyłki i dodatkowo sprawia, że lata 2004-2012 oraz 2013-2018 nie są w pełni porównywalne pod względem liczby tworzonych przez cudzoziemców wynalazków, jednak wydaje się, że w przypadku podejmowanych badań jest to relatywnie nieistotny problem. Spośród 145 aplikacji „złożonych przez cudzoziemców” w latach 2004-2012, jedynie w sześciu obywatelstwo cudzoziemca wynalazcy nie pokrywało się z miejscem jego rezydencji (zob. pkt 2.2). W tych kilku aplikacjach cudzoziemcy wskazali Polskę jako miejsce rezydencji, co prawdopodobnie oznacza, że mieszkali w Polsce na stałe. Pozostali cudzoziemcy, wskazując jako miejsce zamieszkania kraj, którego są jednocześnie obywatelami, prawdopodobnie przebywali w Polsce jedynie czasowo. Z dużym prawdopodobieństwem można zatem przyjąć, że skoro spośród 145 aplikacji złożonych na przestrzeni 9 lat, jedynie w sześciu cudzoziemcy-wynalazcy wskazali Polskę jako miejsce pobytu, to $w$ kolejnych 6 latach struktura miejsc rezydencji cudzoziemców będzie podobna. Oznacza to, że ryzyko nieuwzględnienia wynalazków tworzonych przez cudzoziemców jest ograniczone raptem do kilku.

\section{Imigranci w Polsce: wielkość i struktura}

Wprawdzie Polska obecnie jest krajem bardziej wysyłającym niż przyjmującym migrantów, jednak w przyszłości ten trend może ulec zmianie (White 2018), tzn. Polska może stać się krajem głównie imigracyjnym lub też ważnym krajem docelowym i źródłowym jednocześnie. Jak się przewiduje, ze względu na rosnący dobrobyt, wszystkie państwa UE mają szansę stać się miejscami, do których więcej osób napływa niż odpływa, z tym, że prawdopodobnie ten proces będzie zachodzić etapowo. W pierwszej kolejności należy się spodziewać napływu tymczasowej migracji zarobkowej, a dopiero w dalszej kolejności pozostałych form migracji (White 2018). Ponieważ w Polsce widoczna jest właśnie taka tymczasowa migracja o charakterze zarobkowym, prawdopodobnie nie będzie ona widoczna w większości danych statystycznych, które ujmują jedynie migrantów stałych.

Według danych Organizacji Narodów Zjednoczonych (ONZ 2017) w 2017 r. w Polsce mieszkało prawie 650 tys. osób urodzonych za granicą, które stanowiły 
1,7\% populacji kraju. Od 2015 r. ich liczba zwiększyła się o 4,8\%, jednak w porównaniu z rokiem 2005 obniżyła się o 11,3\%. W tym miejscu należy jednak wziąć pod uwagę, że dane ONZ nie uwzględniają migrantów mających status rezydenta (pracownika) czasowego, zatem prawdopodobnie liczba imigrantów przebywających w Polsce jest w tym ujęciu niedoszacowana, zwłaszcza jeśli chodzi o ostatnie lata. Od 2013 r., w związku z rosyjsko-ukraińskim konfliktem zbrojnym, nasiliła się imigracja obywateli Ukrainy do Polski, których zasadniczo cechuje czasowość i cyrkulacyjność pobytu (Górny, Kindler 2018).

Głównymi kierunkami napływu imigrantów do Polski są państwa sąsiadujące z Polską, choć widocznymi grupami cudzoziemców są również osoby pochodzące z dalszych destynacji. W 2017 r., podobnie jak we wcześniejszych latach, zasób imigrantów stanowili przede wszystkim obywatele Ukrainy, Niemiec i Białorusi, natomiast w dalszej kolejności Litwy, Federacji Rosyjskiej, Wielkiej Brytanii i Francji (wykres 1.).

Spośród zasobu imigrantów zamieszkałych w Polsce, dużą część stanowią osoby wysoko wykwalifikowane. Pod tym względem Polska wyróżnia się nie tylko na tle państw Europy Środkowo-Wschodniej, ale również obszaru OECD. W 2015 r. aż 50\% ogółu cudzoziemców legitymowało się wyższym wykształceniem (wykres 2) i było to o ponad 35 p.p. więcej aniżeli w 2005 r.

Pomimo tak dobrych wyników w zakresie przyciągania wysoko wykwalifikowanych migrantów, Polska stanowi mało atrakcyjną lokalizację dla autorów najcenniejszych artykułów naukowych (ujętych w bazie Scopus). W latach 2002-2016 saldo przepływów netto tej grupy osób było ujemne, co oznacza, że Polska doświadcza większych odpływów autorów artykułów niż ich napływów. Pod tym względem Polska wypada słabo na tle regionu OECD, w tym także państw Europy Środkowo-Wschodniej, ale - co ciekawe - lepiej aniżeli Wielka Brytania, Francja, Japonia czy Niemcy (wykres 3.).

Wykres 1

Struktura imigrantów przebywających w Polsce według kraju pochodzenia w 2017 r.

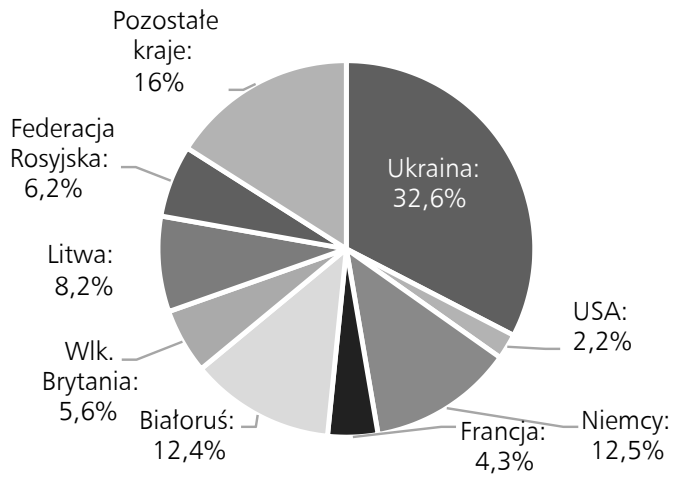

Źródło: opracowanie i obliczenia na podstawie: ONZ (2017). 


\section{SM̂PP}

Wykres 2

Imigranci z osiągniętym trzecim poziomem edukacji jako odsetek ogólnej populacji imigrantów w państwach OECD, 2015 r.

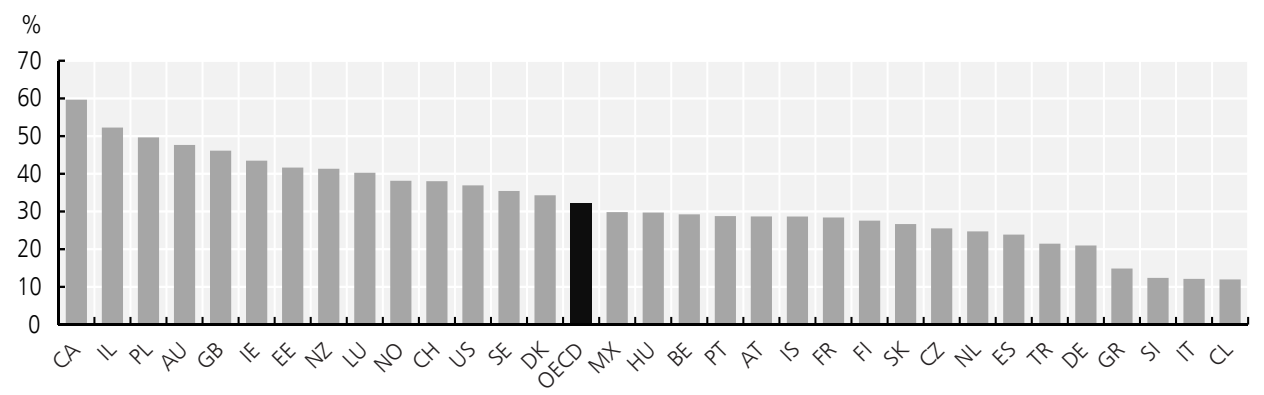

Legenda: CA - Kanada, IL - Izrael, PL - Polska, AU - Australia, GB - Wielka Brytania, IE - Irlandia, EE - Estonia, NZ - Nowa Zelandia, LU - Luksemburg, NO - Norwegia, CH - Szwajcaria, US - Stany Zjednoczone Ameryki, SE Szwecja, DK - Dania, MX - Meksyk, HU - Węgry, BE - Belgia, PT - Portugalia, AT - Austria, IS - Islandia, FR - Francja, FI - Finlandia, SK - Słowacja, CZ - Czechy, NL - Holandia, ES - Hiszpania, TR - Turcja, DE - Niemcy, GR - Grecja, SI - Słowenia, IT - Włochy, CL - Chile.

Źródło: OECD (2017: 127).

Wykres 3

Międzynarodowe przepływy netto autorów artykułów w latach 2002-06, 2006-11, 2011-16 jako procent łącznych przepływów netto autorów artykułów w latach 2002-16

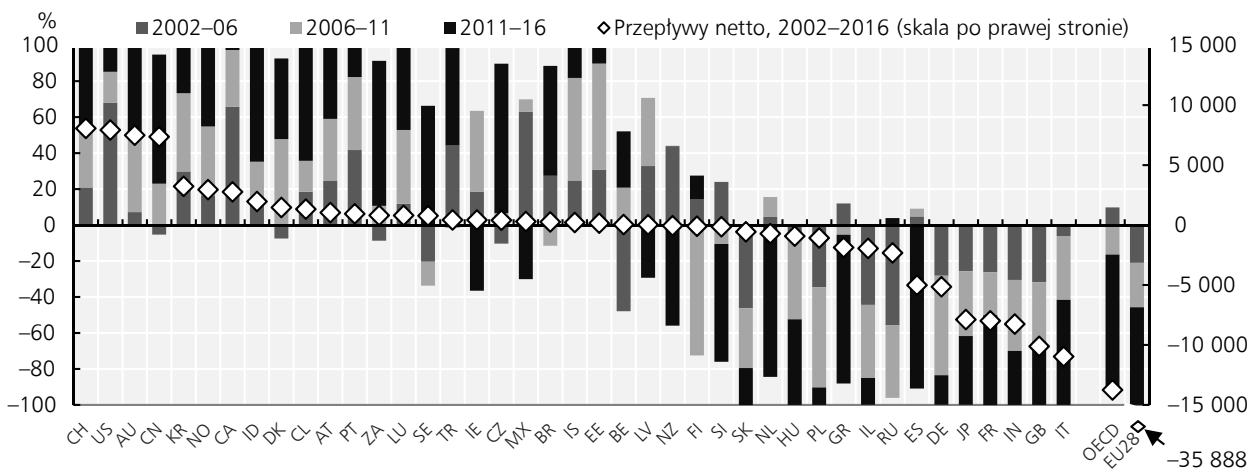

Legenda: CH - Szwajcaria, US - Stany Zjednoczone Ameryki, AU - Australia, CN - Chiny, KR - Korea Południowa, NO - Norwegia, CA - Kanada, ID - Indonezja, DK - Dania, CL - Chile, AT - Austria, PT - Portugalia, ZA - Republika Południowej Afryki, LU - Luksemburg, SE - Szwecja, TR - Turcja, IE - Irlandia, CZ - Czechy, MX - Meksyk, BR - Brazylia, IS - Islandia, EE - Estonia, BE - Belgia, LV - Łotwa, NZ - Nowa Zelandia, FI - Finlandia, SI - Słowenia, SK - Słowacja, NL - Holandia, HU - Węgry, PL - Polska, GR - Grecja, IL - Izrael, RU - Rosja, ES - Hiszpania, DE - Niemcy, JP - Japonia, FR - Francja, IN - Indie, GB - Wielka Brytania, IT - Włochy.

Źródło: OECD (2017: 71).

Z przedstawionych danych dotyczących imigracji wysoko wykwalifikowanej w Polsce wynika zatem, że choć stanowi ona relatywnie wysoki odsetek spośród łącznej liczby migrantów, to niewielu z nich charakteryzuje się wyjątkowymi, specjalistycznymi umiejętnościami i kwalifikacjami. 


\section{Wkład imigrantów w produkt wynalazczy Polski: wyniki badań}

W latach 2004-2018 polskie podmioty zgłosiły łącznie 2549 wynalazków do międzynarodowej ochrony patentowej, z czego 311 zostało stworzonych przez cudzoziemców (samodzielnie lub wspólnie z Polakami). O ile jednak w odniesieniu do aplikacji łącznie można zaobserwować tendencję wyraźnie rosnącą do 2015 r., a następnie wyraźnie opadającą, o tyle liczba wynalazków tworzonych przez cudzoziemców kształtowała się na dość stałym poziomie (wykres 4.). W latach 2004-2018 wahała się od 6 do 41 w skali roku, przy czym w ostatnich 9 latach średnio rocznie odnotowano ich więcej aniżeli we wcześniejszych latach. W okresie 2004-2009 cudzoziemcy odpowiadali za nieco ponad 12 wynalazków rocznie, natomiast w latach 2010-2018 było ich już ponad 26.

Adekwatnie do tego jak wahała się sama liczba wynalazków generowanych przez cudzoziemców, zmieniał się odsetek tworzonych przez nich rozwiązań technicznych, od 6,80\% w 2015 r. do 33,87\% w 2005 r. Spośród wszystkich aplikacji patentowych PCT dokonywanych w latach 2004-2018 na rzecz Polski, zgłoszenia patentowe cudzoziemców stanowiły 12,20\% (wykres 5.).

W latach 2004-2018 największy wkład w podnoszenie produktu wynalazczego Polski wnieśli obywatele Niemiec, a następnie Francji i Stanów Zjednoczonych Ameryki (wykres 6.). Ci pierwsi w całym badanym okresie stworzyli łącznie 73 rozwiązania techniczne, natomiast obywatele Francji i USA, odpowiednio 38 i 35 (wykres 6.).

Wykres 4

Liczba wynalazków PCT generowanych przez cudzoziemców na rzecz Polski w zestawieniu z liczbą wynalazków PCT zgłaszanych do ochrony patentowej przez polskie podmioty ogółem w latach 2004-2018

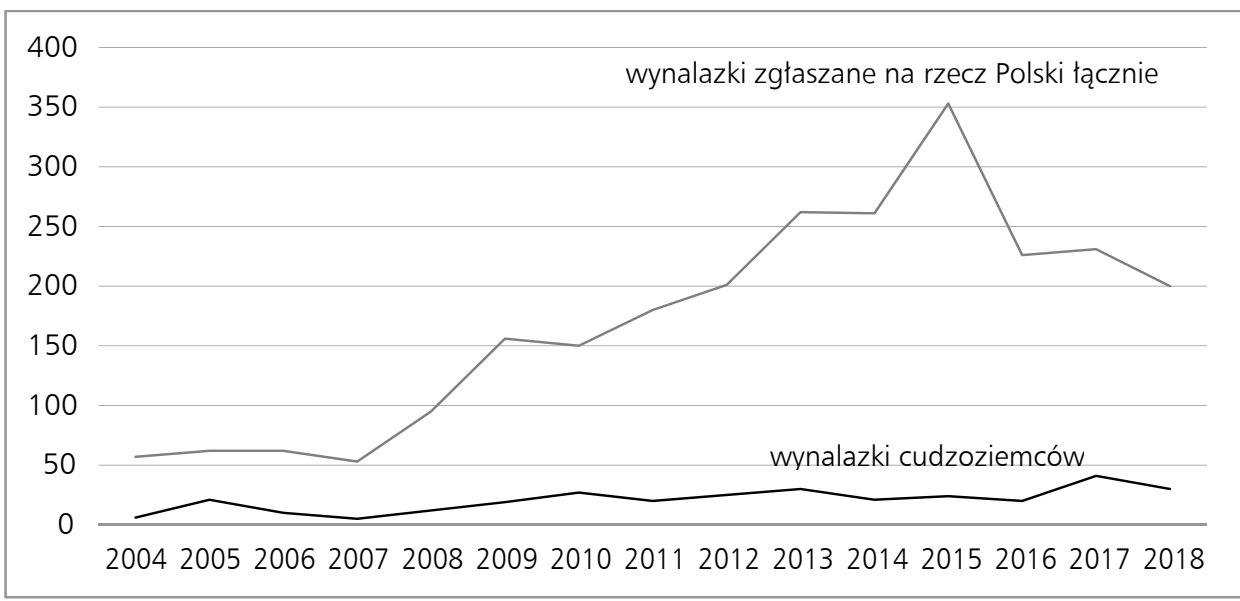

Źródło: opracowanie na podstawie badań własnych. 
Wykres 5

Odsetek wynalazków PCT zgłaszanych na rzecz Polski generowanych przez cudzoziemców w latach 2004-2018

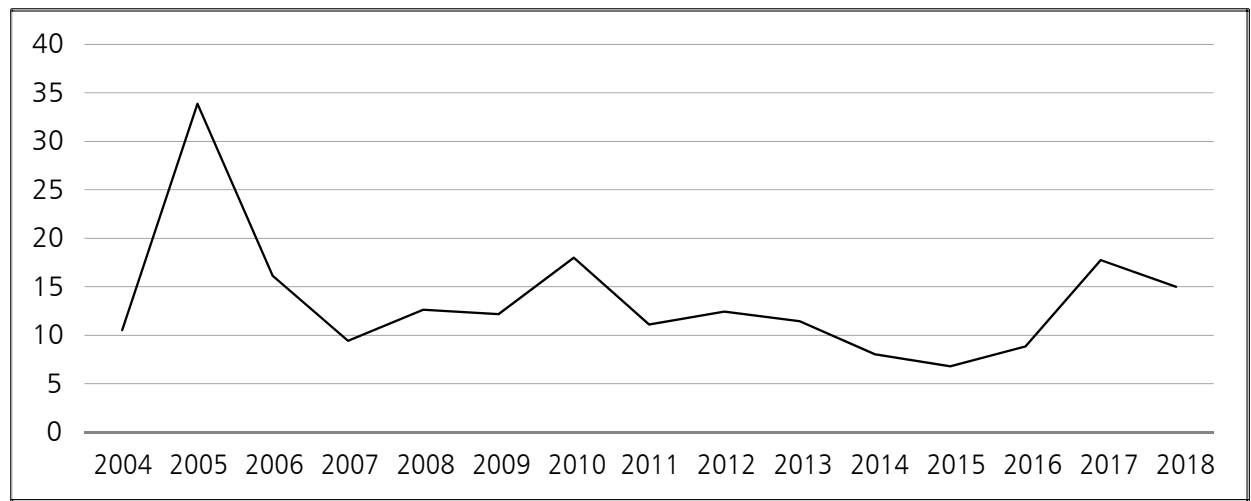

Źródło: opracowanie na podstawie badań własnych.

Wykres 6

Łączna liczba wynalazków PCT wygenerowanych na rzecz Polski przez cudzoziemców w latach 2004-2012 oraz 2013-2018 według kraju obywatelstwa*

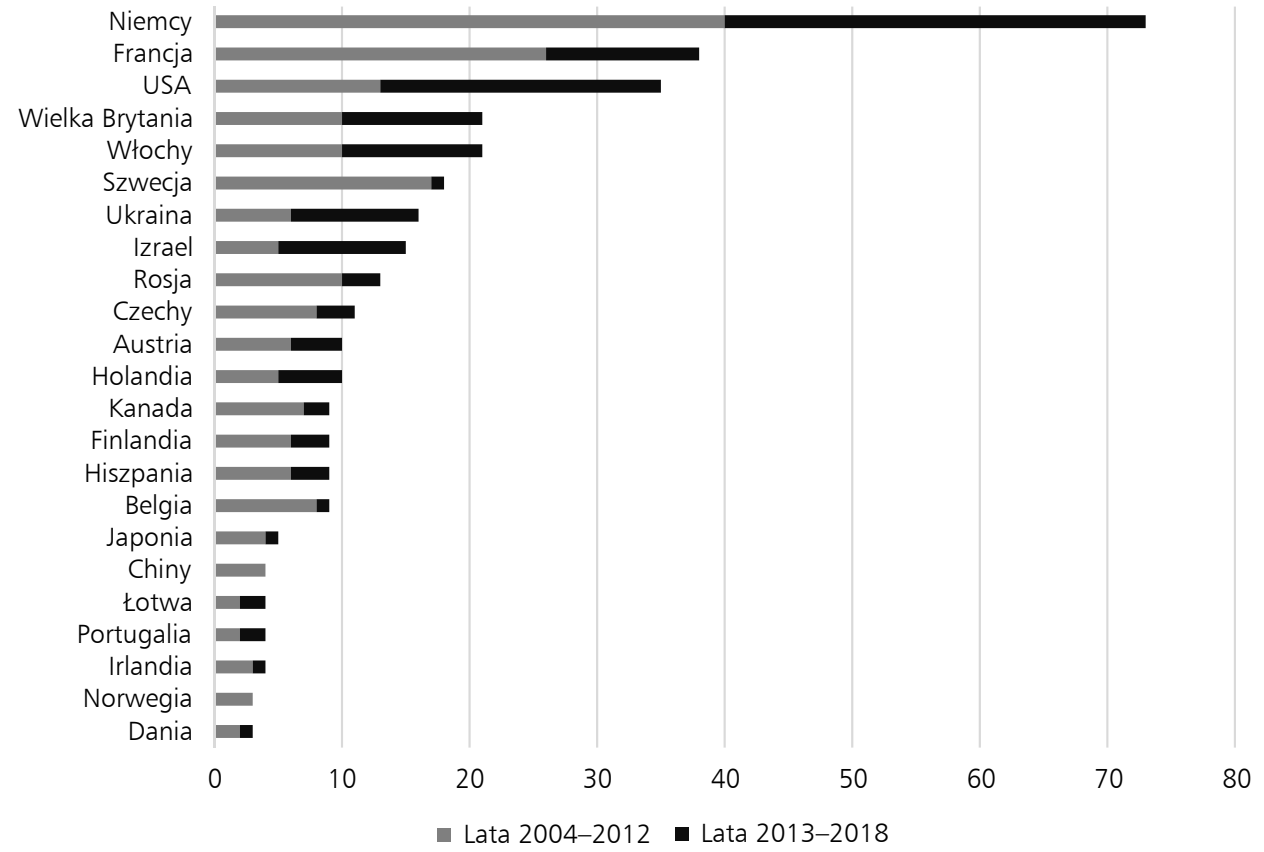

* Łączna liczba wynalazków stworzonych przez obywateli poszczególnych państw nie sumuje się do 311, czyli do łącznej liczby wynalazków należących do cudzoziemców. Wynika to z faktu, że w niektórych przypadkach twórcami jednego wynalazku było kilku cudzoziemców posiadających obywatelstwa różnych państw.

Źródło: opracowanie na podstawie badań własnych. 
Co ciekawe, wynalazki niektórych grup cudzoziemców wyraźnie zanikają, podczas gdy innych pojawiają się. Dla przykładu w latach 2013-2018 (6 lat) liczba wynalazków stworzonych przez obywateli USA była zdecydowanie wyższa aniżeli we wcześniejszych latach 2004-2012 (9 lat). W ciągu pierwszych 9 lat objętych badaniem Amerykanie stworzyli 13 wynalazków, natomiast w ciągu kolejnych sześciu aż 22. Podobną sytuację można zaobserwować w przypadku wynalazków obywateli Ukrainy oraz Izraela. Również w tym przypadku liczba wynalazków z raptem sześciu lat (2013-2018) przewyższała tę z dziewięciu lat (2004-2012). W przeciwieństwie do tego, wynalazki Norwegów i Chińczyków zupełnie zanikły, a liczba rozwiązań technicznych obywateli Szwecji, Czech, Belgii i Japonii znacząco się obniżyła.

Z przeprowadzonej analizy wynika także, że wśród wynalazków PCT generowanych przez cudzoziemców dominowały rozwiązania zaliczane do działów techniki: (1) podstawowe potrzeby ludzkie; (2) budowa maszyn; (3) chemia, metalurgia; (4) różne procesy przemysłowe. W ujęciu sektorowym, większość wynalazków generowanych przez cudzoziemców było zgłaszanych do ochrony patentowej przez przedsiębiorstwa z Polski. Pozostałe wynalazki należały głównie do publicznego sektora nauki.

\section{Zakończenie}

W literaturze na temat wysoko wykwalifikowanej migracji podkreśla się, że wynalazcy-migranci ułatwiają transfer know-how między różnymi gospodarkami narodowymi i są w stanie połączyć zasoby wiedzy pochodzące z różnych lokalizacji. Stają się zatem swoistym pomostem między gospodarką macierzystą a goszczącą, co może być korzystne dla obu zaangażowanych stron, w tym dla innowacyjności kraju przyjmującego. Niniejszy artykuł miał na celu uzupełnić zasoby tej literatury o wskazanie korzyści wynikających z międzynarodowej mobilności wynalazców PCT z perspektywy produktu wynalazczego Polski. Dokładniej celem artykułu była odpowiedź na dwa pytania. Po pierwsze, ile wynalazków PCT tworzą cudzoziemcy na rzecz polskich podmiotów? Po drugie, czy większa liczba imigrantów napływających do Polski przekłada się na wzrost wynalazków PCT tworzonych przez cudzoziemców.

Na podstawie analizy 2549 dokumentów dotyczących wynalazków zgłoszonych w latach 2004-2018 do międzynarodowej ochrony patentowej przez polskie podmioty stwierdzono, że ponad 12\% z nich (tj. 311) zostało stworzonych przez cudzoziemców - głównie obywateli Niemiec, Francji i USA. Ogólnie można uznać, że stanowią one dość sporą część polskiego produktu wynalazczego z tego okresu, jednak wbrew oczekiwaniom, ani liczba, ani udział wynalazków tworzonych przez cudzoziemców nie podążają za ogólną liczbą imigrantów napływających do Polski. Większy napływ cudzoziemców, odnotowywany zwłaszcza od lat 2013-2015, nie skutkuje automatycznie wzrostem rozwiązań technicznych, które są tworzone przez obywateli obcych państw. Liczba wynalazków tworzonych każdego roku przez 


\section{SM̂PP}

cudzoziemców jest ogólnie bardzo zbliżona, zwłaszcza w ostatnich dziewięciu latach (2010-2018), w których kształtuje się na poziomie od 20 do 30 wynalazków rocznie.

Ta dość stabilna liczba wynalazków tworzonych przez cudzoziemców, niezależnie od liczby imigrantów w Polsce, wynika po części z tego, że liczba wynalazków niektórych grup etnicznych wynalazców-cudzoziemców wyraźnie się zmniejsza (czasem wręcz zanika), zaś innych znacząco rośnie, być może w wyniku zmiany struktury imigrantów napływających do Polski. Wskazywałby na to chociażby przykład wynalazków obywateli Ukrainy, których jest wyraźnie więcej wraz z tym, jak nasiliła się ich imigracja do Polski (od 2013 r.). Mimo to wciąż nie jest jasne, dlaczego liczba wynalazków cudzoziemców nie wzrasta w takim stopniu, w jakim wynikałoby to ze wzrostu liczby imigrantów. Można jedynie domniemywać, że przeciętnie obecnie napływający cudzoziemcy są w mniejszym stopniu wysokiej klasy specjalistami i w związku z tym mniejszy odsetek z nich jest wynalazcami. Natomiast w grupach imigrantów, których wynalazki zanikają dominowały jednostki wybitne, stąd zmniejszenie liczebności takiej grupy skutkuje niewspółmiernie większą uratą wynalazków.

Ogólnie z przeprowadzonej analizy wynika, że struktura etniczna imigrantów przebywających w Polsce nie pokrywa się ze strukturą etniczną wynalazków tworzonych w Polsce przez cudzoziemców. Spośród wynalazków cudzoziemców, największą liczbę stanowią bowiem rozwiązania techniczne obywateli Niemiec, następnie Francji i USA, a w dalszej kolejności Wielkiej Brytanii i Włoch, natomiast głównymi grupami imigrantów przebywających w Polsce są osoby pochodzące z Ukrainy, następnie Niemiec i Białorusi, a w dalszej kolejności Litwy. Ten brak ścisłego powiązania między liczebnością określonej grupy migrantów a ich wkładem w produkt wynalazczy Polski potwierdza wcześniejsze spostrzeżenie, w świetle którego wynalazcy wywodzą się z określonych grup etnicznych migrantów i nie zawsze muszą być to te najliczniejsze.

Wyniki analizy podjętej w artykule mogą być użyteczne z perspektywy przyszłych badań, które mogłyby zostać rozciągnięte na większą liczbę państw. Z perspektywy Polski interesujące mogłoby być porównanie z innymi państwami Europy Środkowo-Wschodniej.

\section{Bibliografia}

Agrawal A., Kapur D., McHale J., Oettl A. (2011), Brain drain or brain bank? The impact of skilled emigration on poor-country innovation, „Journal of Urban Economics”, no. 69, s. 43-55.

Bahar D., Choudhury P., Rapoport H. (2019), Migrant inventors and the technological advantage of nations, WP 19-119, Harvard Business School.

Basset-Jones N. (2005), The Paradox of Diversity Management, Creativity and Innovation, "Creativity and Innovation Management", Vol. 14, s. 169-75.

Bratti M., Conti Ch. (2018), The effect of immigration on innovation in Italy, "Regional Studies", Vol. 52, Issue 7, s. 934-947. 
Chellaraj G., K.E. Maskus and A. Mattoo (2005), „The Contribution of Skilled Immigration and International Graduate Students to U.S. Innovation." World Bank Policy Research Working Paper 3588.

Edler J., Fier H., Grimpe Ch. (2011), International scientist mobility and the locus of knowledge and technology transfer, "Research Policy”, Vol. 40, Issue 6, s. 791-805.

Garapich M.P., Grabowska I., Jaźwińska E. (2018), Migracje poakcesyjne z Polski, w: M. Lesińska, M. Okólski (red.), 25 wykładów o migracjach, Warszawa: Wydawnictwo Naukowe SCHOLAR, s. 208-220.

Górny A., Kindler M. (2018), Cudzoziemcy w Polsce na przełomie XX i XXI wieku, w: M. Lesińska, M. Okólski (red.), 25 wykładów o migracjach, Warszawa: Wyd. Naukowe SCHOLAR, s. $221-234$.

Grabowska-Lusińska I., Okólski M., (2009), Emigracja ostatnia?, Warszawa: Wydawnictwo Naukowe SCHOLAR.

Hunt J. (2011), Which Immigrants Are Most Innovative and Entrepreneurial? Distinctions by Entry Visa, "Journal of Labor Economics", 29(3), s. 417-457.

Hunt J., Gauthier-Loiselle M. (2010), How much does immigration boots innovation?, „American Economic Journal: Macroeconomics", Vol. 2, Issue 2, s. 31-56.

Kaczmarczyk P. (2015), Poland: Large migration outflows and skill-mismatch, w: A. Schellinger (red.), Brain drain - brain gain: European labour markets in times of crisis, Bonn: Friedrich-Ebert-Stiftung, s. 33-43.

Kerr W. (2009), Breakthrough inventors and migrating clusters of innovation, NBER WP, no. 15443.

Kerr W., Lincoln W.F. (2010), The supply side of innovation: H-1B Visa Reforms and U.S. Ethnic Invention, „Journal of Labor Economics”, vol. 28, no. 3, s. 473-508.

Kerr W.R. (2008a), Ethnic Scientific Communities and International Technology Diffusion, "The Review of Economics and Statistics", vol. 90, no. 3, s. 518-537.

Kerr W.R. (2008b), The Ethnic Composition of US Inventors, HBS WP, no. 08-006.

Kim J., Lee S.J., Marschke G. (2009), International Knowledge Flows. Evidence from an Inventor-Firm Matched Data Set, w: R.B. Freeman, D.L. Goroff (red.), Science and Engineering Careers in the United States: An Analysis of Markets and Employment, University of Chicago Press, s. 321-348.

Lesińska M., Okólski M., Slany K., Solga B. (2014), Dekada członkostwa Polski w UE: społeczne skutki emigracji Polaków po 2004 roku, Warszawa: Wydawnictwa Uniwersytetu Warszawskiego. Miguelez E., Fink C. (2013), Measuring the International Mobility of Inventors: A New Database, „WIPO Working Paper", no 8.

Nathan M. (2015), Same difference? Minority ethnic inventors, diversity and innovation in the UK, „Journal of Economic Geography”, vol. 15, no. 1, s. 129-168.

Niebuhr A. (2010), Migration and innovation: Does cultural diversity matter for regional $R \& D$ activity?, „Papers in Regional Science”, vol. 89, no. 3, s. 563-585.

OECD (2017), OECD Science, Technology and Industry Scoreboard 2017: The digital transformation, OECD Publishing, Paris, https://doi.org/10.1787/9789264268821-en.

Oettl A., Agrawal A. (2008), International labor mobility and knowledge flow externalities, Journal of International Business Studies, vol. 39, no. 8, s. 1242-1260.

Okólski M. (2009), Polska jako aktor na europejskiej scenie migracyjnej, w: M. Duszczyk, M. Lesińska (red.), Współczesne migracje: dylematy Europy i Polski, Warszawa: Ośrodek Badań nad Migracjami, s. 7-14. 
ONZ (2017), United Nations, Department of Economic and Social Affairs. Population Division. Trends in International Migrant Stock: The 2017 revision (United Nations database, POP/DB/ MIG/Stock/Rev.2017).

Ozgen C, Nijkamp P., Poot J. (2013), The impact of cultural diversity on firm innovation: evidence from Dutch micro-data, „IZA Journals of Migration”, Vol. 2, s. 1-24.

Parrotta P., Pozzoli D., Pytlikova M. (2012), The Nexus between Labor Diversity and Firm's Innovation, "IZA Discussion Paper", no 6972, s. 1-36.

Partridge J., Furtan W.H. (2008), Increasing Canada's International Competitiveness: Is There a Link between Skilled Immigrants and Innovation?, 2008 Annual Meeting, July 27-29, Orlando, Florida 6504, American Agricultural Economics Association (New Name 2008: Agricultural and Applied Economics Association).

Stephan P.E., Levin S.G. (2001), Exceptional contributions to US science by the foreign-born and foreign-educated, „Population Research and Policy Review”, vol. 20, no. 1-2, s. 59-79.

Wadhwa V., Jasso G., Rissing B., Gereffi G., Freeman R. (2007), Intellectual Property, the Immigration Backlog, and a Reverse Brain-Drain. America's New Immigrant Entrepreneurs, Part III, Kauffman Foundation.

White A. (2018), The impact of migration into Poland by non-Poles, w: A. White, I. Grabowska, P. Kaczmarczyk, K. Slany, The impact of migration on Poland. EU mobility and social change, London: UCL PRESS, s. 213-226. 